\title{
Pseudopapillary Pattern
}

National Cancer Institute

\section{Source}

National Cancer Institute. Pseudopapillary Pattern. NCI Thesaurus. Code C35912.

A morphologic finding indicating the presence of poorly cohesive neoplastic cells arranged around fibrovascular cores in a tissue sample. 